\title{
Historein
}

Vol $10(2010)$

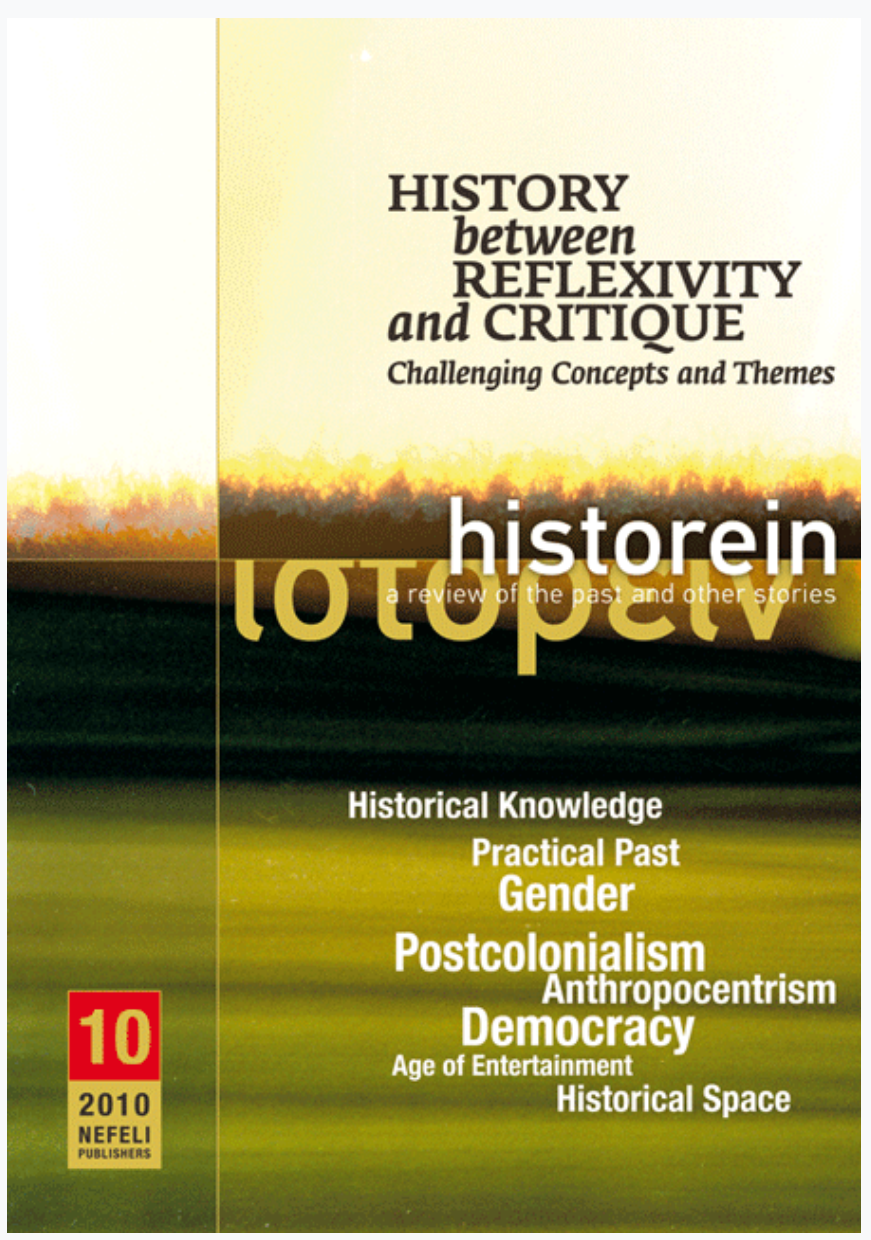

\section{Beyond Anthropocentrism in Historical Studies}

\section{Ewa Domanska}

doi: $10.12681 /$ historein.11

and CRITIQZUE

doi. $\underline{10.12681 / \text { istorein.11 }}$

Copyright ๑ 2012, Ewa Domanska

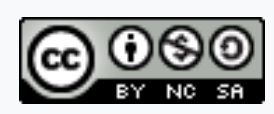

This work is licensed under a Creative Commons Attribution-NonCommercialShareAlike 4.0.

\section{To cite this article:}

Domanska, E. (2011). Beyond Anthropocentrism in Historical Studies. Historein, 10, 118-130.

https://doi.org/10.12681/historein.11 


\section{Beyond}

\section{Anthropocentrism in Historical Studies}

As a theoretician of history interested in the comparative theory of the human sciences, I am trying to reflect on certain changes, turns and approaches that are observable in contemporary human and social sciences. I see the growing interest in nonhuman beings (flourishing animal studies, plant studies and thing studies) within the context of an emerging paradigm of non-anthropocentric human sciences, and I would like to consider certain problems and questions that I see as fundamental for the kind of future-oriented knowledge about the past that these new tendencies portend.

What I mean by anthropocentrism here is the attitude that presents the human species as the centre of the world, enjoying hegemony over other beings and functioning as masters of a nature which exists to serve its needs. This attitude leads to speciesism (assigning different values or rights to beings on the basis of their species membership) and is related to the kind of discrimination that is practiced by man against other species. Optimally, a non-anthropocentric paradigm seeks to de-centre human beings and focus on nonhumans as subjects of research (often quite apart from their relationships with humans).

I would define "non-anthropocentric humanities"1 or posthumanities as an institutionalised set of research topics, techniques and interests that derives its ethos from the intellectual movement and ethical stance called posthumanism. This ethical stance may be understood as a variety of approaches that carry on the legacy of the humanities 
after humanism in pursuing non- or anti-anthropocentric lines of inquiry. The problem of posthumanism is very complex because there are no singular, homogenic trends, styles of thinking or philosophical directions that can be related to this term. ${ }^{2}$ The spectrum of this perspective goes from discussions of the ethical treatment of animals, through the boundaries of species identity, transgenics and cross-species hybrids to biometrics. There is no doubt, however, that a common basis of all these trends and tendencies is the problematisation, critique and/or rejection of anthropocentrism. ${ }^{3}$ Key research problems addressed by the posthumanities include the boundaries of species identity, the relations between the human and the nonhuman (human beings' affiliations with technology, the environment, animals, things), and questions of biopower, biopolitics and biotechnology. As stressed by Cary Wolfe, the editor of a series of books entitled "Posthumanities", 4 there is no intention to somehow reject humanism as such and the values related to it. The intention is rather to consider how those values (justice, tolerance, equality, dignity, human rights, etc.) became a part of the definition of uniqueness and exceptionality of the human kind. The aim is to unbury the genealogy of what today is called posthumanities. These analyses are supposed to anticipate the shape of the "humanities" in the future, i.e. when the humanities become the posthumanities. $^{5}$

\section{The inadequacy of current theories for contemporary global problems}

Knowledge is relative and every theory is created in a particular time and place as a result of particular needs, and thus should be constantly verified. In the context of the emerging posthumanities, it is crucial that we study approaches related to postmodernism from a historical perspective, treating their heroes (Foucault, Derrida, Lyotard, Geertz, Said and White in the theory of history) not as avant-garde authorities for future research but as classics of the genre. Those thinkers and their methodologies must be historicised and contextualised. ${ }^{6}$ This is not to say that they are not important for today's research; this is not to say that they are not relevant. But I think that at present the theory of the human and social sciences is a step behind what is going on in the contemporary world in terms of environmental cataclysms, the crisis of climate change and, in terms of technology, genetic engineering and nanotechnology (plus the spread of global capitalism), and thus must bring under consideration the new situations and phenomena that technology has created. Theory has to "catch up" with the main problems addressed by current research since existing theories and interpretive tools are inadequate to account for the rapidly changing world. ${ }^{7}$

This inadequacy of current theories for problems that surround us has been observed in historical studies for several years now; ${ }^{8}$ however, recently it was highlighted by a well-known scholar in the field of postcolonial studies and a representative of the so-called Subaltern school of historiography - Dipesh Chakrabarty. His recent article "The Climate of History: Four Theses" (2009) marked also a spectacular and revealing shift of his scholarly interests. Chakrabarty de- 
fines himself as "a practicing historian with a strong interest in the nature of history as a form of knowledge". ' In this article, he reflects on the collapse of the old humanist distinction between natural history and human history. Chakrabarty claims that we might trace its beginning to the Industrial Revolution, but only recently, in the second half of the twentieth century, did we become "geological agents", meaning humans became a force of nature, having a tremendous impact on the planet on a geological scale. He proposes that historians should speak more about species (and their mass extinction), about the problem of our collective self-recognition and "should think of humans as a form of life and look on human history as part of the history of life ... on this planet". ${ }^{10}$ Certainly Chakrabarty is well aware of the dangers of the kinds of universals that postcolonial studies were fighting against, but nevertheless he is not afraid to call for a "negative universal history" that arises from a shared sense of a catastrophe (climate change)." For my argument presented here, of special importance is the fact that he is explicit about the inadequacies of present approaches and theories in dealing with various ecological crises. Thus, Chakrabarty confesses: "As the crisis [the current planetary crisis of climate change - ED] gathered momentum in the last few years, I realised that all my readings in theories of globalisation, Marxist analysis of capital, subaltern studies, and postcolonial criticism over the last twenty-five years, while enormously useful in studying globalisation, had not really prepared me for making sense of this planetary conjuncture within which humanity finds itself today."12

This honest statement is just a sign that theoretically oriented scholars are becoming more and more aware that, after the postmodernist turn to fragmented reality, micronarrative (microhistory) and local histories, there is a need to reconsider "big picture questions".

\section{A justification for a nonanthropocentric approach}

Where can we find a justification for a nonanthropocentric approach? What is the validity of such knowledge? In other words: what do we need for this nonanthropocentric paradigm?

Let me begin with a statement that I often heard from Hayden White while participating in his seminars and lectures: "To be a historian is not a choice of career. It is an existential choice." Following this important remark, I would say that to speak about going beyond anthropocentrism or about posthumanism is not to pick up a fancy theme; it is not to consider an epistemological approach, but it is mainly a future-oriented ethical choice. Observing the results of ecological crisis and rapid technological progress and especially recent achievements in genetic engineering, biotechnology, neuropharmacology and nanotechnology, I am convinced that as historians and intellectuals we should again think about "big picture questions", about global questions.

In the 1970s, a Polish scholar, Henryk Skolimowski, introduced the concept of eco-philosophy, which questioned the survival value of the kind of scientific knowledge which took physics with its restrictive rationality and objectivity as its paradigm. "Our knowledge," he wrote in 1974, "and we should never forget this - is a supreme instrument in aiding the species in the process of survival". ${ }^{13}$ But, knowledge has to evolve and change together with the evolution of species and according to the cognitive needs of the human species. Skolimowski pointed out that, in the in- 
terest of preserving the human species, we do not need abstract knowledge but a knowledge that contributes to its survival.

Despite an Enlightened trust in knowledge as a "supreme instrument," I find this argument quite convincing. Indeed, if we consider the host of publications on the Holocaust, we cannot avoid being struck by the way that the knowledge we have produced has failed to prevent the crimes against humanity during the war in former Yugoslavia or the genocide in Rwanda. So, if we ask the question: what kind of humanities do we need today? I might answer that we need the kind of knowledge, cognition and human science that have survival value and might help in the protection and continuation of the species.

It seems that in contemporary intellectual practice scholars are not connected by methods or theories but by the problems on which they focus their intellectual efforts, primarily because those problems are directly or indirectly related to controlling the life and death (biopolitics, necropolitics) of humans, on the one hand, and protecting "life" on earth, on the other. Protecting life is a "paternalistic" project and we have to be very aware of its results. Some scholars would call it "enlightened anthropocentrism" insomuch as it takes under consideration nature and nonhumans and presupposes that our ethical care for nature and nonhumans comes from our care of and responsibility to humans. This idea would be rejected by scholars working in the paradigm of "deep ecology" or the Gaia theory, who claim that nature or the earth will take care of itself. ${ }^{14}$ Also, we should not forget that life (and the survival of species) is not necessarily the highest value for everybody. ${ }^{15}$ Obviously, during the process of evolution, some specia become extinct and new ones appear and we should not desperately seek to preserve them. So, the survival paradigm is not by any means an unquestionable absolute.

Historians themselves also express their awareness of this problem while asking: "How often do we consider the unwelcome but ineluctable ecological fact that, while life on earth could survive just fine without humans (indeed it would no doubt flourish in our absence), without ants the entire foundation would crumble?"16

Keeping in mind the limitations of the survival paradigm, let us make the following assumption: the challenge for today's research is not so much in asking new questions and proposing new theories or methods of analysis, which would spring from current research trends in humanities, but to place the research itself in the context of the emerging paradigm of nonanthropocentric knowledge, or posthumanities. Andrew Pickering called this strategy a "posthumanist displacement of our interpretative frameworks". ${ }^{17}$ Of course, the point is not to eliminate the human being from our studies (of the past) but - as I mentioned above - to displace the human subject from the centre of historical, archaeological and anthropological studies.

I would suggest that in the face of an ecological crisis and radical transformation of what it means to be human caused by genetic engineering and psychopharmacology, we need the kind of knowledge, cognition and human science that has survival value and will help in the protection and continuation of the species. Thus, a big question for "future friendly" historical studies would be: what kind of research questions, research materials, theories and approaches 
should we - as historians and intellectuals - promote in order to strengthen the survival value of knowledge produced by reflection on the past? Are these questions about justice, ethics, democracy, freedom, human rights, dignity, God or the sacred? Which of the cognitive categories used by us should be turned into normative categories? What categories should be established as normative?

\section{Towards collectives of humans and nonhumans}

I attempt to move beyond debates about historical narration, historical representation, and, generally speaking, relations between text and past reality, debates which predominated in historical theory from the mid-1960s to the mid-1990s. I propose that it is time to challenge and transcend the specific approach to the past called history understood as "the science of people in time" (Marc Bloch) and its not only eurocentric and phallocentric but, above all, anthropocentric character. Our reflection about the past should extend to those nonhuman beings that have recently been studied across various disciplines. Today, with the development of insurrectional and militant historiography, things, plants and nonhuman animals should also be incorporated into history as something other than passive recipients of human actions.

The future of thinking about the past will depend on whether and how scholars manage to modify their understanding of nonhuman agents: nonhuman animals, plants and things. Questions concerning the status of nonhuman agents in the past, relations between the human and the non-human, the organic and the inorganic, between people and things and between things themselves are of fundamental importance for reconceptualising the study of the past. Therefore, an important challenge is to rethink the nonhuman aspect of the past in a context other than semiotics, discourse theory or representation theory, with a special focus on the materiality, concreteness, relations and interactions and so-called presence of the past. ${ }^{18}$

What we need is to establish a human-nonhuman relationship based on a nonanthropocentric approach and on a relational epistemology. As anthropologist Nurit Bird-David has shown, thinking based on relational epistemology is marked by an absence of the ontological dualism of nature and culture, and body and mind, that are characteristic of western thought; self and personhood are relational to, and not separated from, the world. The world in this approach is a heterarchical one, rather than hierarchical. "I relate, therefore I am," writes Bird-David, describing the intimate engagements of the natives with their environment. Moreover, she does not reify the notion of "relationship" into an entity but prefers to talk about "relatedness' meaning two beings/things mutually responsive to one other". ${ }^{19}$

Scholars influenced by Bruno Latour are interested in how humans and nonhumans interact through various processes of mediation and actually form collectives; how through various crossovers they exchange their properties. The term "relational epistemology" is also used by Latour, especially in his actor-network theory. ${ }^{20}$ Referring to a collective of humans and nonhumans, this epistemology - as it is in Bird-David's approach - rejects the positivist view of objects or actors as closed and separated from the world, existing in themselves prior to any par- 
ticipation in ecosocial and semiotic networks of interactions (including the interactions in which they are observed, named, etc.).

The need for such an approach in historical studies has been observed also by historians themselves, especially those who are interested in environmental history. For example, Ted Steinberg is well aware that "we need a less anthropocentric and less arrogant view" of the concept of human agency, while Richard D. Foltz, in a Latourian mode, claims that history is about interactions and interconnections and we should not limit them to connections between humans since "many of our most significant historical interactions have been and continue to be with non-humans". Calling for the integration of environmental history with world history, he claims that "world history, if done properly - that is expanding the theme of interactions to include all actors, not just human ones - is not only good scholarship; it may be vital to saving the planet!"21

Latour's project of critical sociology, that is a point of reference for many scholars interested in transcending anthropocentrism, is primarily the study of the collective of humans and nonhumans, especially the evolution of their relations as well as the emergence and transformation of new associations. His actor-network theory is not a critique of metanarratives, nor is it concerned with dissemination or deconstruction. Rather, it is an attempt to go beyond postmodern ways of thinking. For example, the French scholar claims that "objectivity does not refer to a special quality of the mind, an inner state of justice and fairness, but to the presence of objects which have been rendered able ... to object to what is told about them." ${ }^{22}$ Conceived in this way, objectivity is synonymous with the creation of the conditions for resistance or protest on the part of objects. Latour continues:

If social scientists wanted to become objective, they would have to find the very rare, costly, local, miraculous, situation where they can render their subject of study as much as possible able to object to what is said about them, to be as disobedient as possible to the protocol, and to be as capable to raise their own questions in their own terms and not in those of the scientists whose interests they do not have to share! $!^{23}$

The quest for the resisting object - an object resistant to dominant theories - could be the goal of the project of nonanthropocentric reflection about the past. This idea fits with Andrew Pickering's call for the quest for - what he calls - "strange objects": "The work in question in science studies seeks above all to display empirically the existence of some strange objects in the world: assemblages of people and things, the human and the nonhuman, in which the evolution of the former helps to structure that of the latter and vice versa." ${ }^{24}$

According to Pickering, these strange objects, assemblages, challenge classical social sciences since they are "impure"; they transgress traditional disciplinary borders and, if seriously considered, could change the definition of various human and social disciplines.

I took this challenge seriously, and following Latour's and Pickering's remarks, several years ago, I began my own search for disobedient, strange and impure objects. In 2003 in California, I conducted interviews with several directors of local funeral homes. I was interested in how new technology is used to preserve human remains. I was particularly fascinated by the so-called 
LifeGem - the synthetic diamond made from human ashes. ${ }^{25}$ For me, it was an interesting case of going beyond the relationship of the organic and nonorganic. More or less at the same time, I heard about the transgenic, fluorescent rabbit produced by Eduardo Kac, an artwork known as the "GFP Bunny". This transgenic animal does not exist in nature. It is a product of genetic engineering and, as Kac says, Alba was created in order to "examine the notions of normalcy, heterogeneity, purity, hybridity, and otherness; to consider a nonsemiotic notion of communication as the sharing of genetic material across traditional species barriers". ${ }^{26}$ In 2002, two artists from the Royal College of Art, Georg Tremmel and Shiho Fukuhara, presented a project called Biopresence. ${ }^{27}$ The goal of Biopresence was to introduce human DNA into a tree, without changing the genes of the resulting plant, in order to create "living memorials" or "transgenic tombstones". A couple of years ago, there was the story of Oscar Pistorius (known as "Blade Runner"), who has prosthetic legs and breaks records in running races but was not admitted to the Olympic Games because of his "superhuman" abilities.

I did careful studies of these examples of "strange objects", and I discovered that the various theoretical approaches I know about (semiotics, psychoanalysis, discourse theories, poststructuralism, hermeneutics, etc.) did not help me understand the most fundamental aspect of all of them: which is to say, the way they transcend the binary oppositions between organic and inorganic, the natural and the artificial, human and nonhuman. Indeed, all the abovementioned approaches seemed to me to be too abstract, too textual. Actually, I was looking for an approach that would transgress and go beyond the cultural and social determinism of a constructivist view and be more materialist, more ontological; that would allow me to understand this transformation of organic into inorganic; human into nonhuman. In a word, the analysis of these phenomena was a challenge. While we are witnessing the appearance of real subjects which do not fit our familiar topoi, the human sciences do not have the theoretical instruments to describe them and cannot conceptualise them fast enough.

More and more, the humanities are extending their debates about identity, alterity and exclusion to encompass nonhuman entities: animals, plants and things. The other is understood not only as something of a different race, gender, class, sexual or religious orientation, but also someone or something of a different species and organic status (e.g., something inorganic). Studying various figurations of subjectivity, we may notice that the conventional criteria based on the cultural and social understanding of the subject and the dualist, hierarchical thinking in terms of the organic/ inorganic and human/nonhuman ${ }^{28}$ have become insufficient, while the popular vision of constructivism, which conceives of race, gender and other aspects of identity as products of culture, limits the scope of humanistic research. For example, environmental historian Donald Worster has indicated that the "unexamined cultural determinism which underlies mainstream historiography is just as problematic" as any other type of determinism. ${ }^{29}$ Ted Steinberg, in a less avant-garde mode, complains that, among such historical categories as race, class, gender, ethnicity and sexuality, environment is never mentioned. ${ }^{30}$ Perhaps we should transgress the cultural determinism of the dominant versions of constructivism in a situation in which the interactions between humans and nonhumans and the boundaries of species identity have become major problems in the human sciences. For example, there are currently many discussions on the "return to things" ${ }^{31}$ It does not mean, of course, that things have been totally neglected by historians. On the contrary, the study 
of things is the principal task of the history of material culture. Nonetheless, as I have mentioned above, there is a challenge to find a way of moving beyond both the positivistic description of things and the semiotic approach to the thing as text, symbol or metaphor. Narrativism and textualism "dematerialised" things by comparing the thing to the text and research to reading, and by perceiving the thing as a message or sign. In an attempt to reverse those negative tendencies, "new material studies" point to the agency of things, accentuating the fact that things not only exist but also act and have performative potential. ${ }^{32}$ Of course, the notion of the agency of things does not mean that things have intentions, but that they enjoy a particular status in their relations with people. ${ }^{33}$ For scholars inspired by Marcel Mauss' idea of the gift, things have a socialising function: they solidify interpersonal relations and they participate in the creation of human identity at the individual and collective levels and mark its changes.

Today's prevailing approach to nonhumans in terms of their alterity (animals, plants and things considered as "others") is conservative rather than progressive. It remains within the anthropocentric humanities; within "enlightened anthropocentrism". This approach might also be called paternalism since it presupposes a hegemonic attitude towards nonhuman others. It still implies human mastery and relations of hierarchy but presumes a certain responsibility not only towards other humans but also towards nonhuman beings. In this approach, people act on behalf of nonhumans thereby fulfilling a protective contract. ${ }^{34}$ Such an approach still promotes a colonising discourse in which the nonhuman is treated as the fragile and victimised other in a vein similar to that of women, children and the disabled. This approach leads to a radical personification of animals, plants and things and confirms the perception that treating things and animals like people is a way to readdress questions about the human condition. However, even within the conventional framework of humanistic research, to pose the problem of a nonhuman subject means to challenge the anthropocentric position, and thus make the first step towards stopping the anthropogenetic or "anthropological machine" - to use Giorgio Agamben's term. ${ }^{35}$

There is no need to emphasise that questions about the human condition deserve special attention given the recent interest in biotechnology, biopower and biopolitics, and the problem of the inhumanity of the human that concerns Agamben, for example, still is and always will be of special importance. Agamben's writings prepare a base for posthumanities: however, his project continues in the tradition of thinking that rests at the base of anthropocentrism. It was Agamben who, in The Open, described and analysed the mechanism of the abovementioned "anthropological machine", which produces and determines the divisions between the human being and the animal (many researchers use this concept to dismantle the anthropocentric paradigm). Thus, many of Agamben's concepts are definitely worthy of attention for anyone who would like to work in the posthumanities: the anthropological machine, creating the nonhuman in a human being, the homo sacer, the relation between zoe and bios and the issues of biopower. Reading Agamben I came to the conclusion that perhaps the most important questions are: Do I want to be human? Do I have a sense of belonging to the human species? Do I feel solidarity with the species? 


\section{Possible trajectories for the theory of history in the future}

The proposed topic - "Beyond Anthropocentrism in Historical Studies" - somehow suggests the possible future orientation of our reflection of the past. ${ }^{36}$ We need a new metalanguage, which would require reconciliation between the human and natural sciences, and perhaps closer relations with cognitivist approaches. ${ }^{37}$ As Hayden White said once: "every so often we have this positivist movement" and indeed we are part of one right now. There is a need to rethink constructivism as a dominant tendency (going beyond "cultural determinism") and to take a closer look at so-called new materialism, new empiricism or flat ontology. ${ }^{38}$ We need to become more empirical, focus on building theory from the bottom-up and avoid thinking of theory as a "box of tools" that uses research material and data in an instrumentalist way to justify itself. Such a bottom-up approach to theory has been recently called "théorie concrète" by Patrick Joyce. At issue here is not a theoretical extension over data but the capacity of data to extend our theoretical imagination. Joyce claims that the "science studies" agenda is the best one to challenge the "theory from above" approach since it advocates research-oriented studies and thinking in terms of science-as-practice. "39 "Concrete theory" could help meet some of the basic problems of the contemporary human and social sciences, such as the distinction between nature and culture (or the natural and the social), the human and the nonhuman, material and immaterial and organic and inorganic.

To summarise: we proceed with a bottom-up approach; certain phenomena that we study challenge dominant ways of thinking and available methodologies; thus, based on our findings, we propose new concepts. Indeed, the problem of concept-formation, meaning to invent concepts that are in keeping with the empirical challenges and problems of our time, is absolutely crucial at present. Another possibility - as I mentioned before - would be the rehabilitation and/or reinvention of those "gothic concepts" $\$ 0$ that was forbidden for many years and together with such banned terms as essence, structure and strong subject should be rehabilitated for strategic purposes. Certainly, there is no return, for example, to structuralism after the lessons we learned from deconstruction, textualism and poststructuralism, but I think we might use a strategy of rehabilitation and get rid of the pejorative usage of these terms, so that they are lifted from their historical settings and are pushed in directions that are relevant to today's problems. ${ }^{41}$

I would propose to conceive posthumanities research as a kind of theoretical frame for identifying "the disobedient research object", meaning an object resistant to our present knowledge, and the possibility of conceptualising it. This might be the goal of our project of nonanthropocentric history. 


\section{NOTES}

1 This might be only a working name since this term is too paradoxical to be fully accurate. To some scholars it may seem as an absurd attack the concept of the humanities as a discipline.

2 See Neil Badmington (ed.), Posthumanism, Basingstoke/New York: Palgrave, 2000; Andy Miah, "A Critical History of Posthumanism", in Bert Gordijn and Ruth Chadwick (eds), Medical Enhancement and Posthumanity, Dordrecht: Springer, 2007; Cary Wolfe, What is Posthumanism? Minneapolis: University of Minnesota Press, 2010.

3 There are important differences between approaches to posthumanism that come from, for example, technoscience (scholars like Donna Haraway or Bruno Latour), philosophy and cultural studies (Giorgio Agamben, Rosi Braidotti, Ernesto Esposito, Cary Wolfe), eco-philosophy or from bioart (SymbioticA). For example, SymboticA, The Centre of Excellence in Biological Arts at the University of Western Australia, "is an artistic laboratory dedicated to the research, learning and critique of life sciences. SymbioticA is the first research laboratory of its kind, in that it enables artists and researchers to engage in wet biology practices in a biological science department" (www.symbiotica.uwa.edu.au, accessed 21 February 2010). See Monika Bakke, "Zoe-Philic Desires: Wet Media Art and Beyond", Parallax 14:3 (2008): 21-34.

4 The following books have been published in this series to date, all by the University of Minnesota Press: Michel Serres, The Parasite (2007), Donna Haraway, When Species Meet (2007), David Willis, Dorsality: Thinking Back through Technology and Politics (2008), Roberto Esposito, Bios: Biopolitics and Philosophy (2008); Nicole Shukin, Animal Capital: Rendering Life in Biopolitical Times (2009), John Protevi, Political Affect: Connecting the Social and the Somatic (2009).

5 Cary Wolfe, Introduction to "Posthumanities" series. See www.carywolfe.com/post_about.html, accessed 21 February 2010.

6 The same idea has been expressed by Gabrielle M. Spiegel during her presidential address to the American Historical Association. Gabrielle M. Spiegel, "The Task of the Historian", American Historical Review 114:1 (2009): 1-15.

7 Cf. Francis Fukuyama, Our Posthuman Future: Consequences of the Biotechnology Revolution, New York: Farrar, Straus and Giroux, 2002.

8 This inadequacy has been indicated, for example, by scholars working on environmental history.

9 Dipesh Chakrabarty, “The Climate of History: Four Theses”, Critical Inquiry 35:2 (2009): 197-222 (198).

10 Ibid., 213.

11 lbid., 222.

12 Ibid., 199 and also 212, where Chakrabarty says: "The problematic of globalization allows us to read climate change only as a crisis of capitalist management. While there is no denying that climate change has profoundly to do with the history of capital, a critique that is only a critique of capital is not sufficient for addressing questions relating to human history once the crisis of climate change has been acknowledged and the Anthropocene has begun to loom on the horizon of our present. The geologic now of the Anthropocene has become entangled with the now of human history."

13 Henryk Skolimowski, "Problems of Rationality in Biology", in Francisco Jose Ayala and Theodosius Dobzhansky (eds), Studies in the Philosophy of Biology, Berkeley: University of California Press, 1974, 224. 


\section{Beyond Anthropocentrism in Historical Studies}

14 Cf. James Lovelock, The Ages of Gaia: A Biography of Our Living Earth (rev. and exp. edn), New York: Norton, 1995; Lynn Margulis, Symbiotic Planet: A New Look at Evolution, New York: Basic, 1998; John Gray, Straw Dogs: Thoughts on Humans and Other Animals, London: Granta, 2002.

15 Zygmunt Bauman reflects on the myth of the significance of human life and understands survival as a social relation. He observes that "survival is, potentially, as anti-social as pro-social ... It can be put to socially destructive as much as to socially creative uses." Zygmunt Bauman, "Survival as a Social Construct", Theory, Culture \& Society 9:2 (1992): 1-36 (12).

16 Richard C. Foltz, "Does Nature Have Historical Agency? World History, Environmental History, and How Historians Can Help to Save the Planet?" The History Teacher 37:1 (2003): 9-28 (24).

17 Andrew Pickering, "The Mangle of Practice: Agency and Emergence in the Sociology of Science", The American Journal of Sociology 99:3 (1999): 559-89 (561).

18 Cf. Ewa Domanska, "The Material Presence of the Past", trans. Magdalena Zapedowska, History and Theory 45:3 (2006): 337-48.

19 In a traditional objectivist paradigm speaking about mutual responsivity between beings/things does not make sense, but in Bird-David's approach it is explained as follows: 'If 'cutting trees into parts' [like botanists do in order to study the tropical forest - ED] epitomizes the modernist epistemology, 'talking with trees,' I argue, epitomizes Nayaka animistic epistemology. 'Talking with' is shorthand for a two-way responsive relatedness with a tree - rather than 'speaking' one-way to it, as if it could listen and understand. 'Talking with' stands for attentiveness to variances and invariances in behavior and response of things in states of relatedness and for getting to know such things as they change through the vicissitudes over time of the engagement with them. To 'talk with a tree' - rather than 'cut it down' is to perceive what it does as one acts toward it, being aware concurrently of changes in oneself and the tree. It is expecting response and responding, growing into mutual responsiveness and, furthermore, possibly into mutual responsibility." Nurit Bird-David, "'Animism' Revised. Personhood, Environment, and Relational Epistemology", Current Anthropology 40 (Supplement) (1999): 67-91 (77). See also her "The Giving Environment: Another Perspective on the Economic System of Gatherer-Hunters", Current Anthropology 31:2 (1990): 189-96.

20 Even if ANT was developed much earlier by Michel Callon and Bruno Latour, Latour's Reassembling the Social offers probably the best and the most useful for historians explication of this theory. Bruno Latour, Reassembling the Social: An Introduction to Actor-Network-Theory, Oxford: Oxford UP, 2005.

21 Foltz, “Does Nature Have Historical Agency?" 20, 23 and 11.

22 Bruno Latour, "When Things Strike Back: A Possible Contribution of 'Science Studies' to the Social Sciences", British Journal of Sociology 51:1 (2000): 107-23 (115).

23 lbid., 116.

24 Andrew Pickering, “The Objects of Sociology: A Response to Breslau's 'Sociology After Humanism', Sociological Theory 18:2 (2000): 308-16 (308).

25 See www.lifegem.com (accessed 21 February 2010).

26 See Eduardo Kac, "GFP Bunny”, in Peter T. Dobrila and Aleksandra Kostic (eds), Eduardo Kac: Telepresence, Biotelematics, and Transgenic Art, Maribor: Kibla, 2000, 101-31. Recently Kac has created a new life form - a genetically-engineered flower that is a hybrid of Kac himself and the petunia. It is called 
Edunia and it expresses artist's DNA exclusively in its red veins. See Eduardo Kac, "Life Transformation: Art Mutation", in Eduardo Kac (ed.), Signs of Life: Bio Art and Beyond, Cambridge: MIT Press, 2007.

27 See www.biopresence.com (accessed 21 February 2010).

28 It is worth noting that, from the logical point of view, "human" is not opposed to "nonhuman". The concept of the human can be opposed to that of the animal or the thing, but the concept of the nonhuman is a negation of the human, not an oppositional term.

29 Quoted in Foltz, who refers to his personal communication with Worster. Cf. Foltz, "Does Nature Have Historical Agency?" 23.

30 Ted Steinberg, "Down to Earth: Nature, Agency, and Power of History”, American Historical Review 107:3 (2002): 798-820 (798).

31 While the study of things is not a new field within the humanities, the new approaches and interpretative categories have put it in a completely new light. Things have become a major focus of interdisciplinary projects. For an extended discussion of this development, see Ewa Domanska, "The Return to Things", trans. Magdalena Zapedowska, Archaeologia Polona 44 (2006): 171-85.

32 Addressing the agency of things, scholars often cite the works of Bruno Latour, Pandora's Hope: Essays on the Reality of Science Studies, Cambridge/London: Harvard UP, 1999, and Alfred Gell, Art and Agency, Oxford: Clarendon, 1998.

33 The problem of nonhuman agency has recently attracted the attention of historians. Foltz, who writes about such nonhuman historical actors as cotton, wool, or sheep, is convinced that they have historical agency. He is also well aware that while studying these actors, "the prevailing notions of historical agency need to be challenged". Foltz, "Does Nature Have Historical Agency?" 10 and 22.

34 See Gísli Pálsson, "Human-Environmental Relations: Orientalism, Paternalism and Communalism”, in Philippe Descola and Gisli Pálsson (eds), Nature and Society, London and New York: Routledge, 1996.

35 Giorgio Agamben, The Open: Man and Animal, trans. Kevin Attell, Stanford: Stanford UP, 2004, 33ff. and 80.

36 Perhaps we should also consider using a phrase "reflection about the past" (or studies of the past) rather than historical studies, which narrows our consideration to history understood as a specific approach to the past developed within the framework of the Judeo-Christian tradition.

37 John Zammito seeks a reconciliation between the human and the natural sciences in his article "Toward a Robust Historicism: Historical Practice in a Post-positivist Environment", in Nancy Partner and Sarah Foot (eds), Handbook of Historical Theory, London: Sage, 2009. See also his A Nice Derangement of Epistemes: Post-Positivism in Science Studies from Quine to Latour, Chicago: University of Chicago Press, 2004.

38 Deleuze's empiricism (traced back to 1953 and his study of Hume in the book Empiricism and Subjectivity) offers an alternative to traditional thinking about the connection between theoretical and empirical research. Manuel DeLanda, who is inspired by Deleuze, introduces a concept of "a flat ontology". He offers an alternative foundation for social theory which is a neorealist assemblage theory (networks, cities, markets, nation-states) based on Deleuzian ontology. DeLanda sees reality as autonomous, mindindependent, which is the result of dynamical processes in the organisation of matter and energy that leads to the production of life forms (morphogenesis). Manuel DeLanda, A New Philosophy of Society: 


\section{Beyond Anthropocentrism in Historical Studies}

Assemblage Theory and Social Complexity, London: Continuum, 2006. See also: Nicholas Gane, "Concepts and the 'New' Empiricism", European Journal of Social Theory 12:1 (2009): 83-97

39 Patrick Joyce, “What Is the Social In Social History?” Past and Present 206:1 (2010): 213-248 (216).

40 While referring to the writings of John Rawls and Robert Nizick, Quentin Skinner uses a metaphor of "the 'gothic' vision of liberty" that they try to revive". Quentin Skinner, "Machiavelli on the Maintenance of Liberty", Politics 18 (1983): 3-15 (3).

41 For example, Chakrabarty is rehabilitating the Enlightenment idea of reason when he claims that "in the era of the Anthropocene, we need the Enlightenment (that is, reason) even more than in the past. There is one consideration though that qualifies this optimism about the role of reason and that has to do with the most common shape that freedom takes in human societies: politics." Chakrabarty, "The Climate of History", 211. 